\begin{abstract}
Iranica
Abstracta Iranica Revue bibliographique pour le domaine irano-aryen

Volume 32-33 | 2013

Comptes rendus des publications de 2009-2010
\end{abstract}

\title{
Tim Greenwood. Sasanian Reflections in Armenian Sources
}

\section{Rika Gyselen}

\section{(2) OpenEdition}

1 Journals

\section{Édition électronique}

URL : http://journals.openedition.org/abstractairanica/40496

DOI : 10.4000/abstractairanica.40496

ISSN : 1961-960X

Éditeur :

CNRS (UMR 7528 Mondes iraniens et indiens), Éditions de l'IFRI

\section{Édition imprimée}

Date de publication : 1 décembre 2013

ISSN : 0240-8910

\section{Référence électronique}

Rika Gyselen, «Tim Greenwood. Sasanian Reflections in Armenian Sources », Abstracta Iranica [En ligne], Volume 32-33 | 2013, document 157, mis en ligne le 01 juillet 2016, consulté le 26 septembre 2020.

URL : http://journals.openedition.org/abstractairanica/40496; DOI : https://doi.org/10.4000/ abstractairanica.40496

Ce document a été généré automatiquement le 26 septembre 2020.

Tous droits réservés 


\title{
Tim Greenwood. Sasanian Reflections in Armenian Sources
}

\author{
Rika Gyselen
}

\section{RÉFÉRENCE}

Tim Greenwood. Sasanian Reflections in Armenian Sources. 2010, 34 p. [Sasanika Occasional Papers, II]

1 Comme l'indique le titre de ce fascicule, l'A. a voulu montrer que 'les sources arméniennes reflètent des réalités sassanides'. Après une évaluation de la valeur historique des principales sources arméniennes mises en œuvre, on trouve une sélection de quelques passages ayant un rapport direct avec l'empire sassanide et dont le contenu est confronté à d'autres sources, parfois sassanides et sigillographiques. En appendice, la traduction de deux extraits de la Géographie d'Anania de Širak qui sont symptomatiques d'une transmission peu fiable et de deux inscriptions monumentales qui mettent en évidence qu'en Arménie la référence chronologique s'établit par rapport aux règnes des rois sassanides.

2 Pour une étude systématique de ces mêmes sources par rapport à l'administration sassanide, voir c.r. $\mathrm{n}^{\circ} 163$. 


\section{AUTEURS}

RIKA GYSELEN

CNRS/Mondes iranien et indien, Paris 